\title{
HIBISCUS RHODANTHUS (MALVACEAE) - AN INTERESTING PLANT SPECIES IN SOUTHEASTERN AFRICA ${ }^{1}$
}

\author{
ANNA MEDWECKA-KORNAŚ
}

\begin{abstract}
Hibiscus rhodanthus Gürke ex Schinz (Malvaceae) is a small plant with bright red flowers, herbaceous in the aboveground parts and permanently woody in the underground rootstock. It belongs to the 'geoxylic suffrutices', a group of pyrophytes. The author had an opportunity to observe H. rhodanthus in Zambia, Southeastern Africa. This paper contains information on the genus Hibiscus L., the morphology of the studied species, and the vegetation and climate of Zambia. Newly ascertained localities of $H$. rhodanthus are listed, and data on its occurrence on two permanent plots in tall-grass savanna near Lusaka are given. The above-ground parts of $H$. rhodanthus usually develop soon after burning of vegetation, mainly in the second part of the dry season. Flowers may occur first, then stems and leaves, in full development during the rainy season. The geographic distribution and theories of the origin of 'geoxylic suffrutices' are discussed.
\end{abstract}

Key words: Hibiscus rhodanthus, Zambia, savanna, fire, pyrophytes, suffrutices

Anna Medwecka-Kornaś, Institute of Botany, Jagiellonian University, Lubicz 46, 31-512 Kraków, Poland; e-mail: ubmedwec@ cyf-kr.edu.pl

\section{INTRODUCTION}

Hibiscus rhodanthus Gürke ex Schinz looks like the majority of members in the genus Hibiscus L. - in miniature. It has very pretty flowers (Figs $1,2)$ and can survive vegetation fires owing to its permanent woody underground parts. It belongs therefore to the plants called 'pyrophytes' and to a very peculiar group of them, 'geoxylic suffrutices', or simply 'suffrutices'.

I had an opportunity to observe Hibiscus rhodanthus Gürke ex Schinz and other pyrophytic plant species during my stay in Zambia in 1972-1973. At that time, my husband Jan Kornaś was employed as Professor of Botany at Lusaka University in the country's capital. We made a number of botanical trips, collecting plant specimens and observations. In the following years a number of works of ours were published. The majority of them, written by Jan Kornaś, concern ferns and fern allies and were presented in a review by Tamás Pócs (1993).

\footnotetext{
1 Dedicated to our friend Tamás Pócs, as a memento of the days we spent in Africa together.
}

\section{GENERAL INFORMATION AND MORPHOLOGY} OF H. RHODANTHUS

Hibiscus (Malvaceae) is a cosmopolitan genus numbering $c a 500$ species. Its representatives are native to tropical, subtropical and warm temperate regions and are widely cultivated for their ornamental flowers and for practical use.

Information about Hibiscus in Zambia can be found in a book by White (1962) which focuses mainly on shrubs and trees. $H$. rhodanthus is not mentioned there although some suffrutices belonging to other genera are covered. Fanshawe (1973) included it on a list of species compiled under the heading 'woody plants'. A chapter in Flora Zambesiaca by Exell (1961) contains information on 57 Hibiscus species, but the work refers to a territory larger than present-day Zambia: northern and southern Rhodesia and the adjacent countries. Among the presented members of the genus Hibiscus there are annual and perennial herbs, shrubs and trees. The trees are small, however, and not numerous. Some plants of the same species can represent different types of growth; 


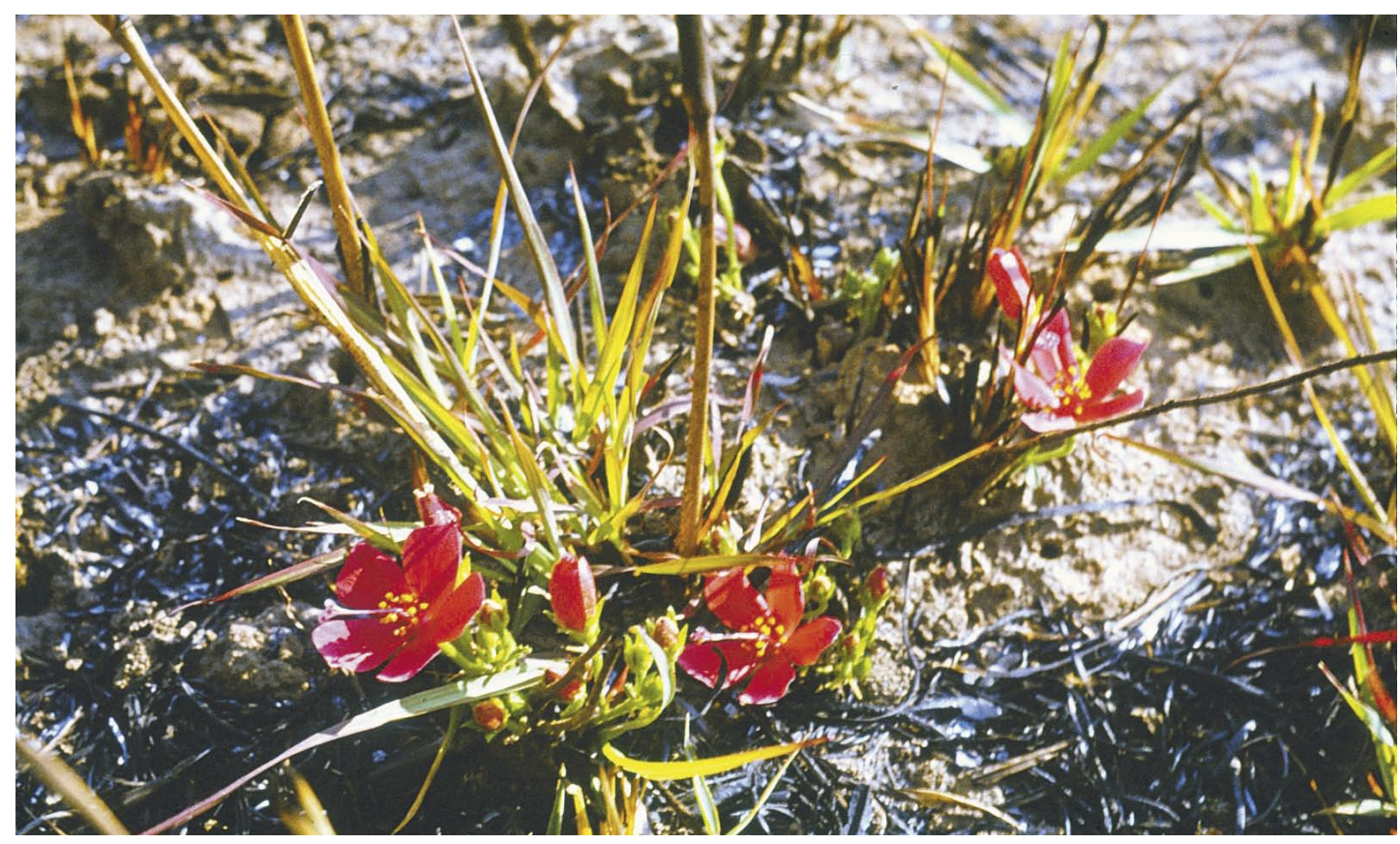

Fig. 1. Hibiscus rhodanthus Gürke ex Schinz in burnt savanna, September 1972 (locality no. 8).

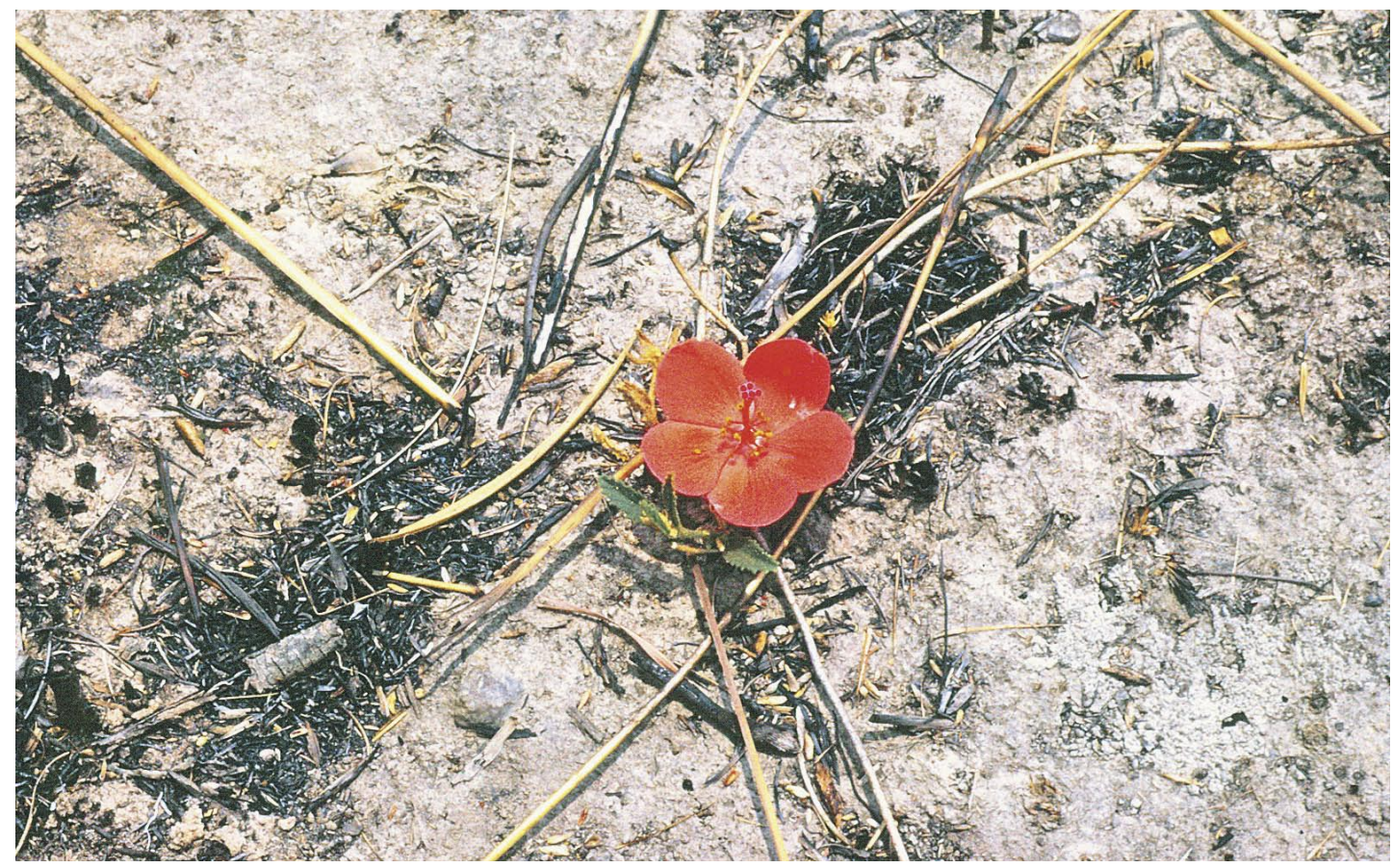

Fig. 2. Hibiscus rhodanthus Gürke ex Schinz in open miombo woodland near Kafue National Park, October 1971 (locality no. 2). 
this is characteristic of the tropics and important in consideration of some problems of evolution (cf. Discussion). Hibiscus calophyllus Cav., for example, can be a herb, a shrub or a small tree (White 1962: 434). Some plants defined in Flora Zambesiaca as 'producing annual shoots from a woody rootstock' belong to the suffrutices. Among them is $H$. rhodanthus.

Hibiscus rhodanthus, distinguished and described in 1895, has woody underground parts but they are not thick ( $c a 0.5-1.5 \mathrm{~cm}$ in diameter) and usually ramified (Figs 3,4). The renovating buds (for aerial shoots) develop on the soil surface or slightly deeper. The flowers appear before or simultaneously with the leaves. They are solitary or in clusters, bright red, $3-4 \mathrm{~cm}$ in diameter, with 5 free petals, a small epicalyx and a larger calyx. The stamens are numerous and united into a tube surrounding the style, the ovary is superior, and the style is simple at the base and branched towards

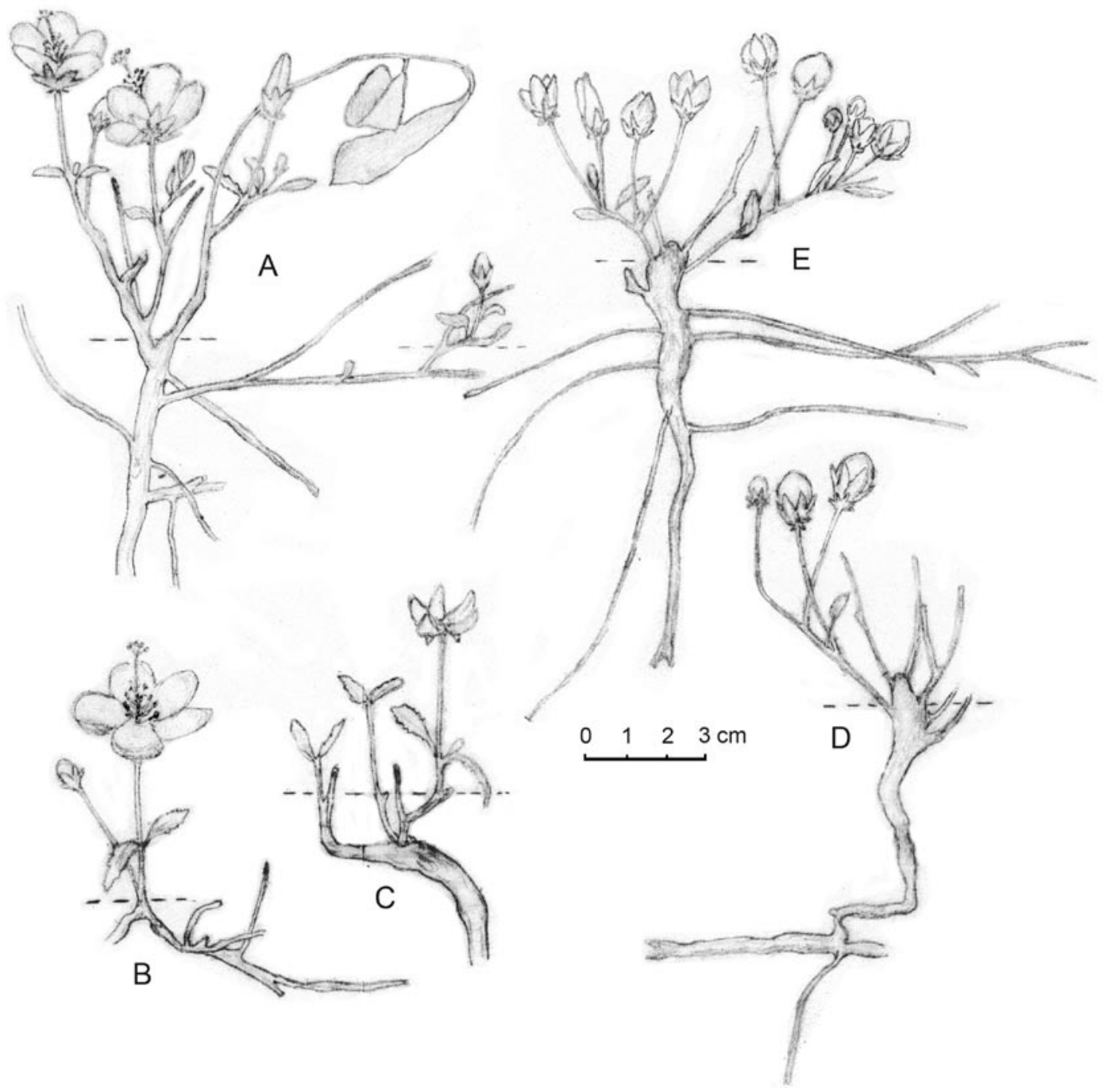

Fig. 3. Hibiscus rhodanthus Gürke ex Schinz - plants with underground woody rootstocks, specimens A, B, C, D from locality no. 4, specimen E from Lusaka University campus (locality no. 5), September and October 1972; hatched lines - soil horizon; drawing by the author. 


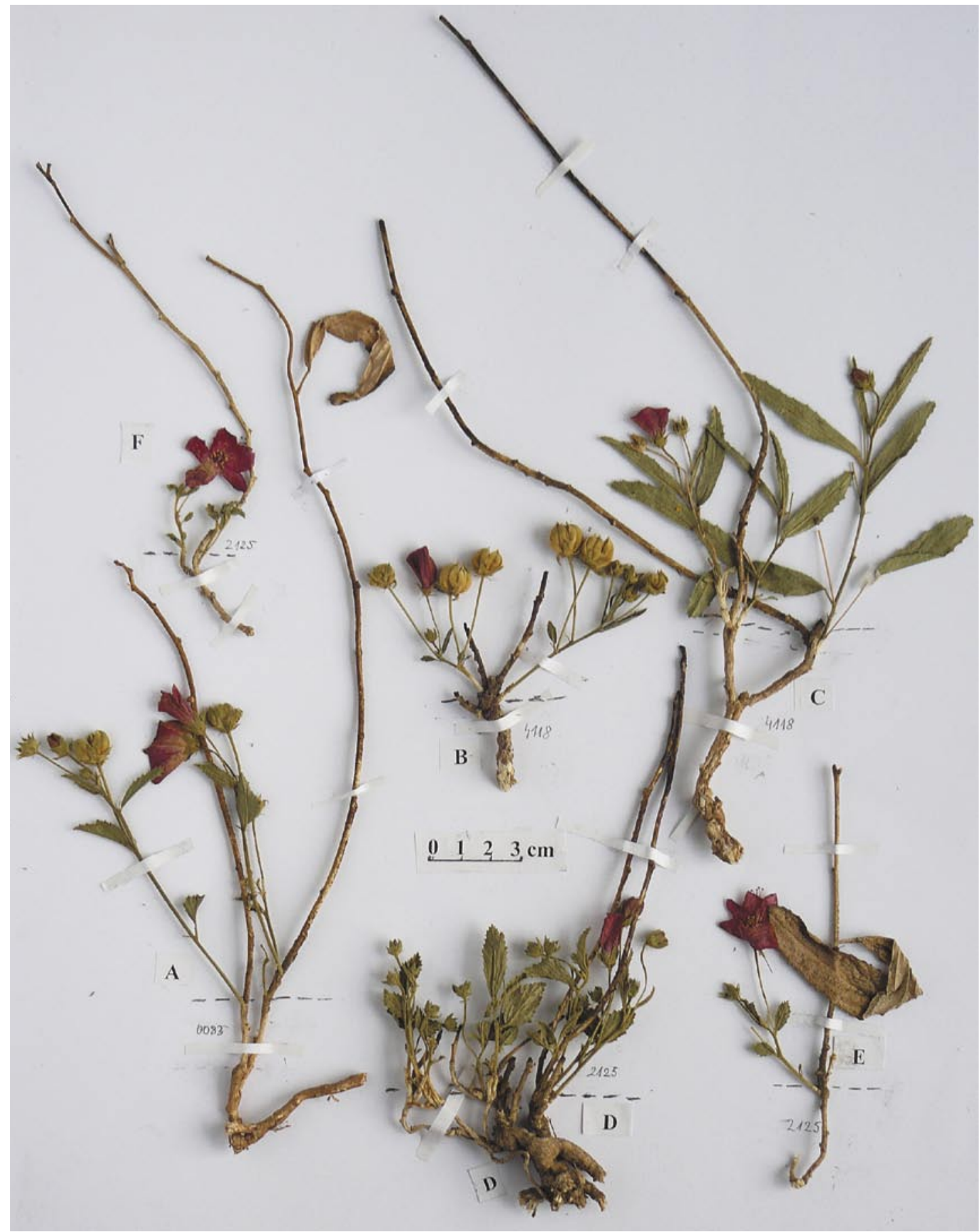

Fig. 4. Hibiscus rhodanthus Gürke ex Schinz - stages of blooming and fructification. Note swollen stem bases and stems with leaves from previous years, September 1972, end of dry season. Near and on Lusaka University campus (A - KRA 0083, B, C - KRA 4118, D, E, F, - KRA 2125). 
the apex together with the stigma. It projects over the stamens and the corolla. The fruit, a small subglobose capsule $\mathrm{ca} 1 \mathrm{~cm}$ in diameter, splits when ripe. The seeds are very numerous, small and with silky floss; they fall off easily. The leaves are oblong or oblong-elliptic, with a serrate margin, in full development up to $10 \mathrm{~cm}$ long (Fig. 5), according to data from Exell (1961) up to $13 \mathrm{~cm}$. The stems, in my observations, can grow up to $c a$ $40 \mathrm{~cm}$, according to Exell (1961) up to $1 \mathrm{~m}$. Some parts of the plant are stellate-setose, stellate-hispid or pubescent.

\section{NATURAL CONDITIONS AND NEW LOCALITIES IN ZAMBIA}

We found Hibiscus rhodanthus in savannas, a miombo woodland and in some other localities, usually after burning of vegetation, and also on two permanent plots near Lusaka. The dominant plant formations in Zambia are savannas with domination of grasses and various shares of trees and shrubs, and above all miombo - open woodland with Brachystegia Benth., Julbernardia Pellegr. and other seasonally green tress (Fig. 6). This is connected with climatic conditions and modified to a high degree by the occurrence of fire. The area has a long dry season lasting from April/May to September/October, with scarce or no precipitation, relatively cool at the beginning and hot at the end, up to $37^{\circ} \mathrm{C}$. The $c a 5$-month rainy season is rather warm. Mean annual precipitation in the Lusaka region is $c a 800 \mathrm{~mm}$ (Fig. 7). The plant biomass, mainly tall grasses produced during the rains, dries later and becomes very susceptible to fire, which is very frequent in the savannas and the miombo forests (Strřmgaard 1992), where dry litter and grasses are present in the ground layer (Fig. 8). The natural conditions and vegetation of Zambia were described by Fanshawe (1971) and in a shorter version by Kornaś (1979), who pointed out the role of fire. This ecological factor has been discussed by a number of authors in relation to savannas (e.g., Gillon 1983) and/or other plant formations (e.g., Philips 1974; Christensen 1985). More recently, Van Langevelde et al. (2003) presented some mathematical formulas and models to describe the effects of fire. Kull (2004) discussed in depth the problems connected with fire in Madagascar, which concern other tropical regions as well (cf. Lüttge 2008, chapter II). Krohmer et al. (2012) address the problem of climate change and the stability of savannas.

During our field studies in Zambia, Hibiscus rhodanthus was recorded - as a rule by phenological observation - in the localities given below. They were registered in notebooks and documented with slides and/or herbarium specimens collected mainly by Jan Kornaś, and also by our son Andrzej, and deposited (with all our collections) in the herbarium of the Botanical Institute of the Jagiellonian University in Kraków (KRA).

\section{LIST OF LOCALITIES}

1. Lusaka, near Lusaka University campus ( $\mathrm{N}$ part of city), grassland (abandoned fields), 9 September 1971: buds, flowers and young fruits, KRA 0083 (Fig. 4A).

2. Kafue National Park (NE of Lusaka), vicinity of Lubungu village, in disturbed miombo woodland, 14 October 1971: flowers (Fig. 2).

3. Leopards Hill Road, ca $26 \mathrm{~km}$ ESE of Lusaka, near miombo woodland, open site at road, 10 August 1972, early stage of flowering, and burned plot, 24 September 1972, full blooming.

4. Between International Airport and Kasisi, ca $20 \mathrm{~km}$ ENE of Lusaka, observation plot no. 1, 30 August 1972, flowers, young leaves; herbarium specimens from 18 September 1972, KRA 2125 (Fig. 4D, E, F).

5. Lusaka, Lusaka University campus, under planted Eucalyptus trees, burned plot, 5 September 1972, flowers, and 19 October 1972, flowers, specimens up to $20 \mathrm{~cm}$ tall.

6. Lusaka, Lusaka University campus, grassland, 6 September 1972, flowers, young leaves; lg. A. Kornaś, KRA 4118 (Fig. 4B, C), and 27 September 1972, flowers, fruits and leaves, lg. A. Kornaś, KRA 4140.

7. Near Ndola (Copperbelt Province, $\mathrm{N}$ of Lusaka), Forest Reserve, miombo woodland after conflagration (burning experiment), 23 September 1972, flowers. 


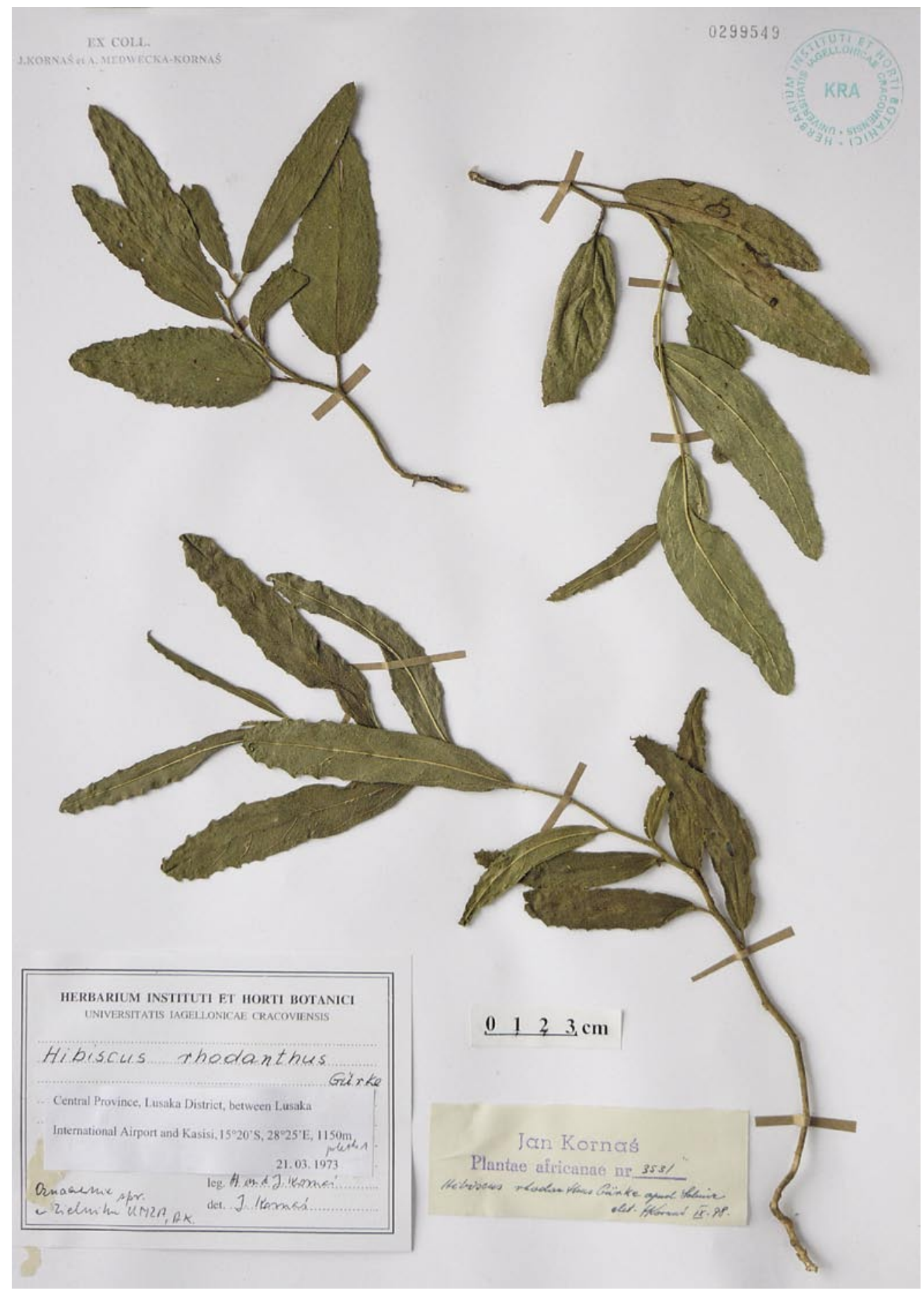

Fig. 5. Hibiscus rhodanthus Gürke ex Schinz in full development of vegetative parts, 21 March 1973, end of rainy season, KRA 3531. 


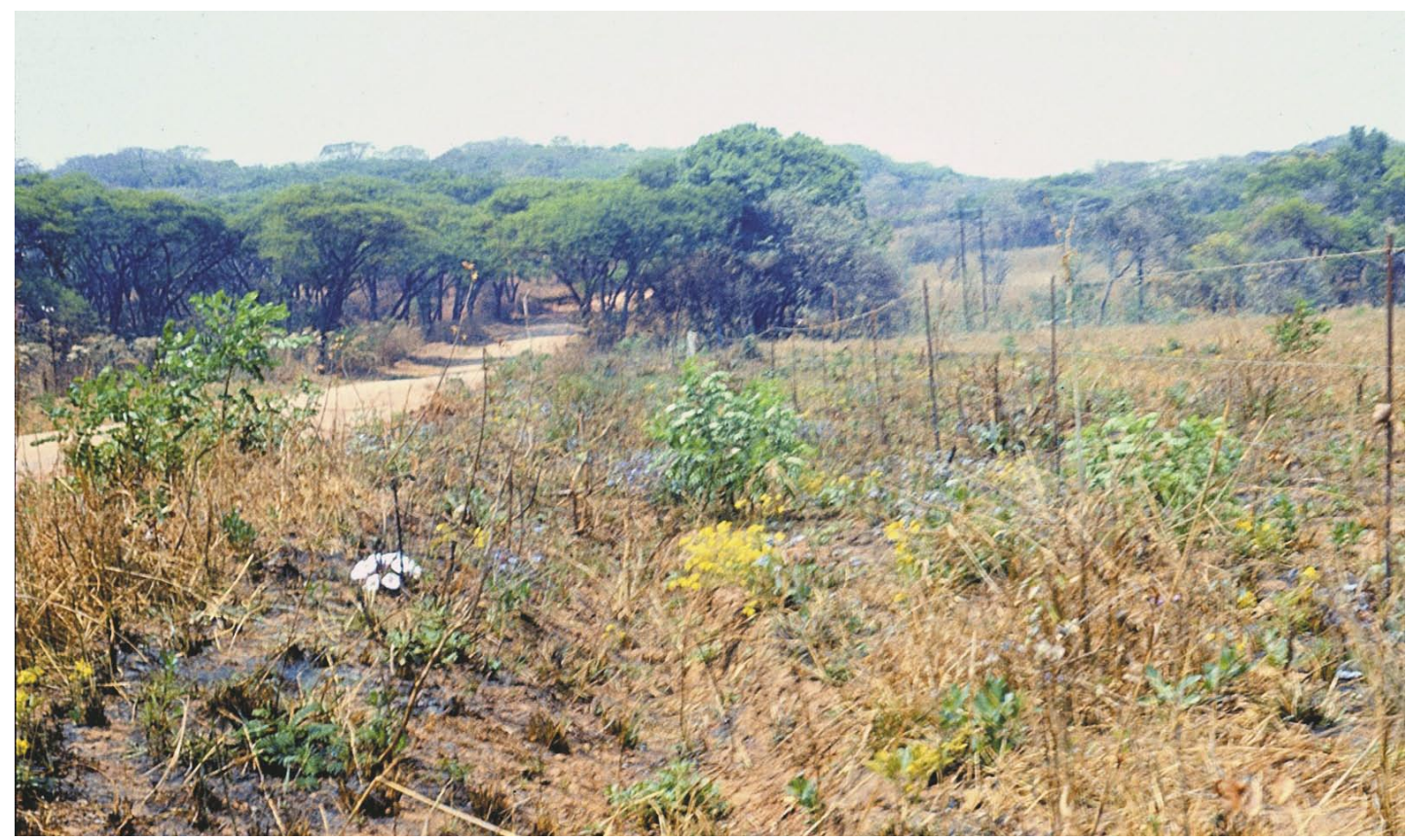

Fig. 6. Road to Leopards Hill, $24 \mathrm{~km}$ ESE of Lusaka. In the foreground, savanna burned some weeks before; at far end, miombo woodland, September 1972.

8. Leopards Hill Road, ca $24 \mathrm{~km}$ ESE from Lusaka, recently burned pasture on roadside, 24 September 1972, flowers (Fig. 1).

9. Between Kasisi and Constantia, ca $30 \mathrm{~km}$ NE of Lusaka, observation plot no. 2, 9 October 1972, flowers and fruits, KRA 2368; March 1973 - leaves (Fig. 5).

10. By road to Mount Makulu Agricultural Research Station, situated ca $15 \mathrm{~km} \mathrm{~S}$ of Lusaka, 26 September 1973, flowers.

From October 1972 to April 1973, Hibiscus rhodanthus was studied more thoroughly on the above-mentioned plot 1 and plot 2 near Lusaka, as described in the next section.

\section{STUDIES ON THE PERMANENT PLOTS}

The two plots chosen for more detailed observations of the vegetation, particular species, and the influence of fire upon them, were situated $c a 20$ (plot 1) and $30 \mathrm{~km}$ (plot 2) northeast of Lusaka (Central African Plateau) at 1150 and $1130 \mathrm{~m}$ a.s.l. respectively. They covered 100 sq. $\mathrm{m}$ each, in tall grass savanna with sparse shares of trees and shrubs on oxisol - choma soil series (plot 1) and latosol - lateric soil (plot 2), according to the USDA classification ${ }^{2}$. The studies used phytosociological records completed according to the widely known method of Braun-Blanquet, and excavation of plants. The observations began $c a$ 2-3 weeks after a conflagration in the second half of the dry season and were repeated at roughly one-month intervals over the rainy season (time of full development of grasses up to $2 \mathrm{~m}$ tall) until the next dry season, when fires appeared in the region.

The most important grasses in the studied savanna were Andropogon schirensis A. Rich., Hyparhenia filipendula (Hohst.) Stapf and $\mathrm{Hy}$ pertelia dissoluta (Nees ex Stand) W. D. Apart from them were some sedges such as Cyperus margaritaceus Vahl., Scleria bulbifera A. Rich. and Fimbystylis complanata (Retz.) Link (investigated separately by Medwecka-Kornaś and

\footnotetext{
2 Information courtesy of N. S. Miljkovic, Professor at Lusaka University in 1972/1973
} 


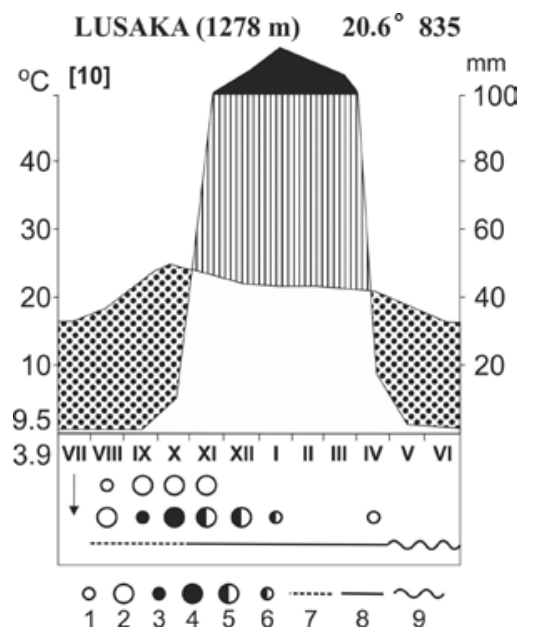

Fig. 7. Climate diagram of Lusaka (above) and phenology of Hibiscus rhodanthus Gürke ex Schinz with data from the permanent observation plots (below). Headings include altitude above sea level, mean annual temperature $\left({ }^{\circ} \mathrm{C}\right)$, mean annual precipitation $(\mathrm{mm})$ and number of observation years (bracketed); figure at bottom left indicates lowest temperature ever recorded (for further explanation see Kornaś 1979). 1 - buds, 2 - flowers, 3 - young fruits, 4 - ripe fruits (capsules), 5 splitting capsules, 6 - end of fructification, 7 - young leaves, 8 - shoots and fully developed leaves, 9 - drying leaves. Arrow indicates date of burning.

Kornaś 1985), as well as numerous dicotyledonous plants such as Triumfetta heliocarpa K. Schum. (Tiliaceae), Indfigofera hillaris Eckl. \& Zeyh. (Fabaceae) and Dicliptera melleri K. Schum (Rolfe) (Acanthaceae) which according to the classification by Raunkiaer belong to the biological group of hemicryptophytes, in typical form, without woody parts. The same group also comprises the above-mentioned grasses and some sedges; geophytes were not numerous. Plants with woody underground parts - geoxylic suffrutices - were relatively numerous. Among them were Lannea edulis (Sond.) Engl. (Anacardiaceae), Cussonia corbisieri De Wild (Araliaceae), Gardenia subacaulis Stapf \& Hutch, previously described in detail (Medwecka-Kornaś 1980), and the presently discussed Hibiscus rhodanthus.

Hibiscus was found at the beginning of the observations (i.e., 2-3 weeks after the fire) as a small, just-then flowering plant. It grew in ash-covered open places between incompletely burned and regenerating tufts of grasses, together with other dicotyledonous plants in blossom. At that stage its coverage was estimated (on the phytosociological scale) as 2.2 , later only 1.1 and + . The fruits of Hibiscus were found very soon, in many cases simultaneously with flowers (Figs 3, 4, 7). Their splitting and seed dissemination took place at the same time or slightly later, but still during the dry season. In the rainy season adult plants of this species were developing and were relatively large, as a rule in the vegetative state. At the time of the rains a well-developed seedling was also found.

\section{DISCUSSION AND CONCLUSIONS}

Hibiscus rhodanthus is mentioned in Flora Zambesiaca (Exell 1961) from 12 (perhaps selected) localities. Six of them were in Zambia, including the Nyika Plateau at $2130 \mathrm{~m}$ a.s.l. (nearly the maximum vertical range of this species), and the six others in Rhodesia, Malawi and Mozambique; according to general information it was also recorded in Angola and Tanzania. During our investigations in several regions of Zambia we encountered only 10 stations of this species, located in Central Province and in one case in Copperbelt Province. In our opinion $H$. rhodanthus apparently is not a very common plant, but in the state without flowers it is difficult to discover. On Fanshawe's (1973) list this species is given for all provinces of Zambia, but without any detailed information.

According to our data, Hibiscus rhodanthus grows in savannas and miombo woodlands as well as on some disturbed plots such as the grassy area at the Lusaka University campus or even in abandoned fields. Fanshawe (1971) mentions it among the species occurring in woodlands: chipya, miombo and munga, and in 'suffrutex savanna'. A very important condition of its distribution is the burning of vegetation, which may occur even every year. Sometimes the plant is also found in other conditions on barren ground, such as a graded roadside space where it grew together with some other pyrophytes.

The observations on the permanent plots near Lusaka and at other sites mentioned above indicate the stimulating role of fire in the development and 


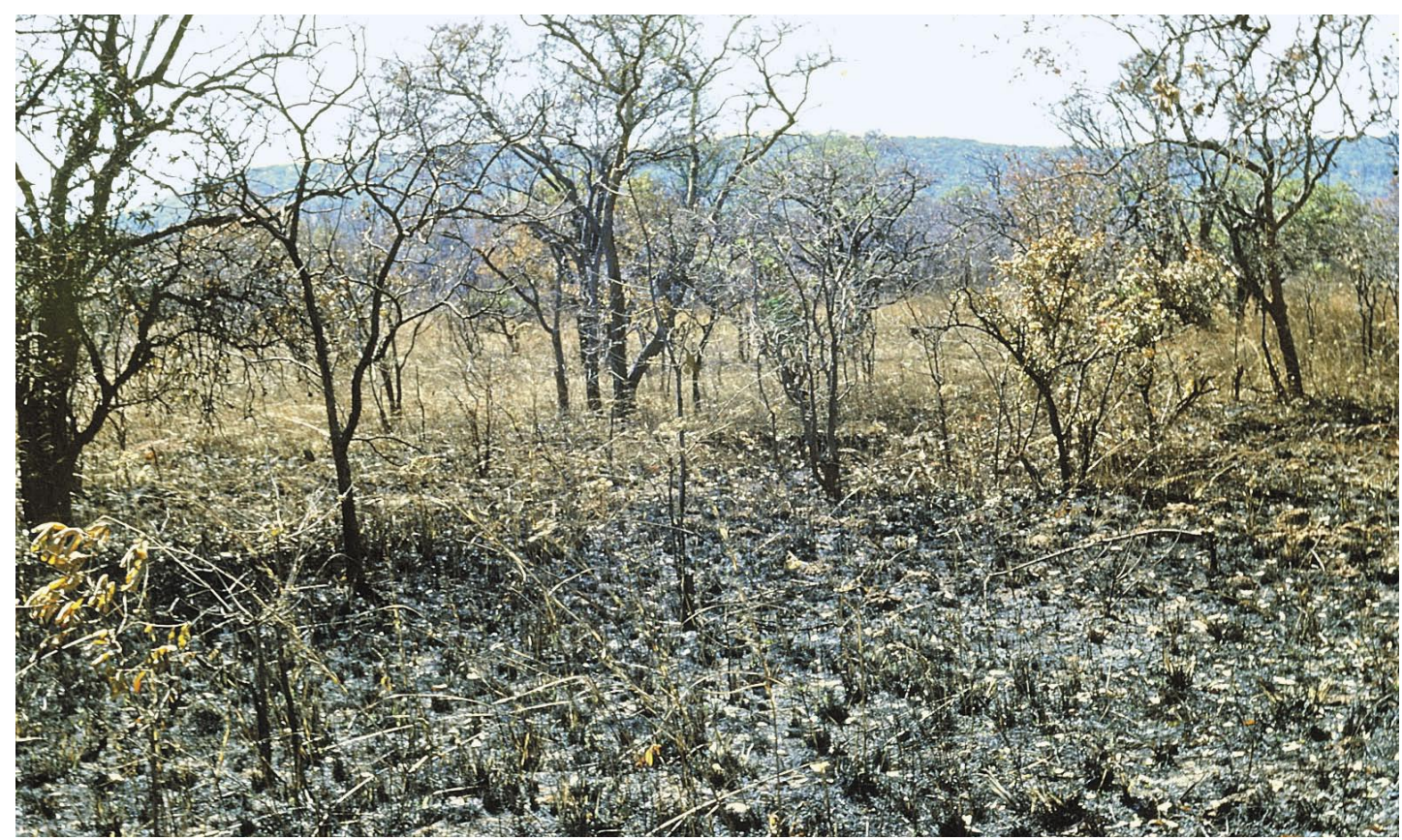

Fig. 8. Miombo woodland after a fire. Lusaka region; on horizon is Leopards Hill, 28 June 1972.

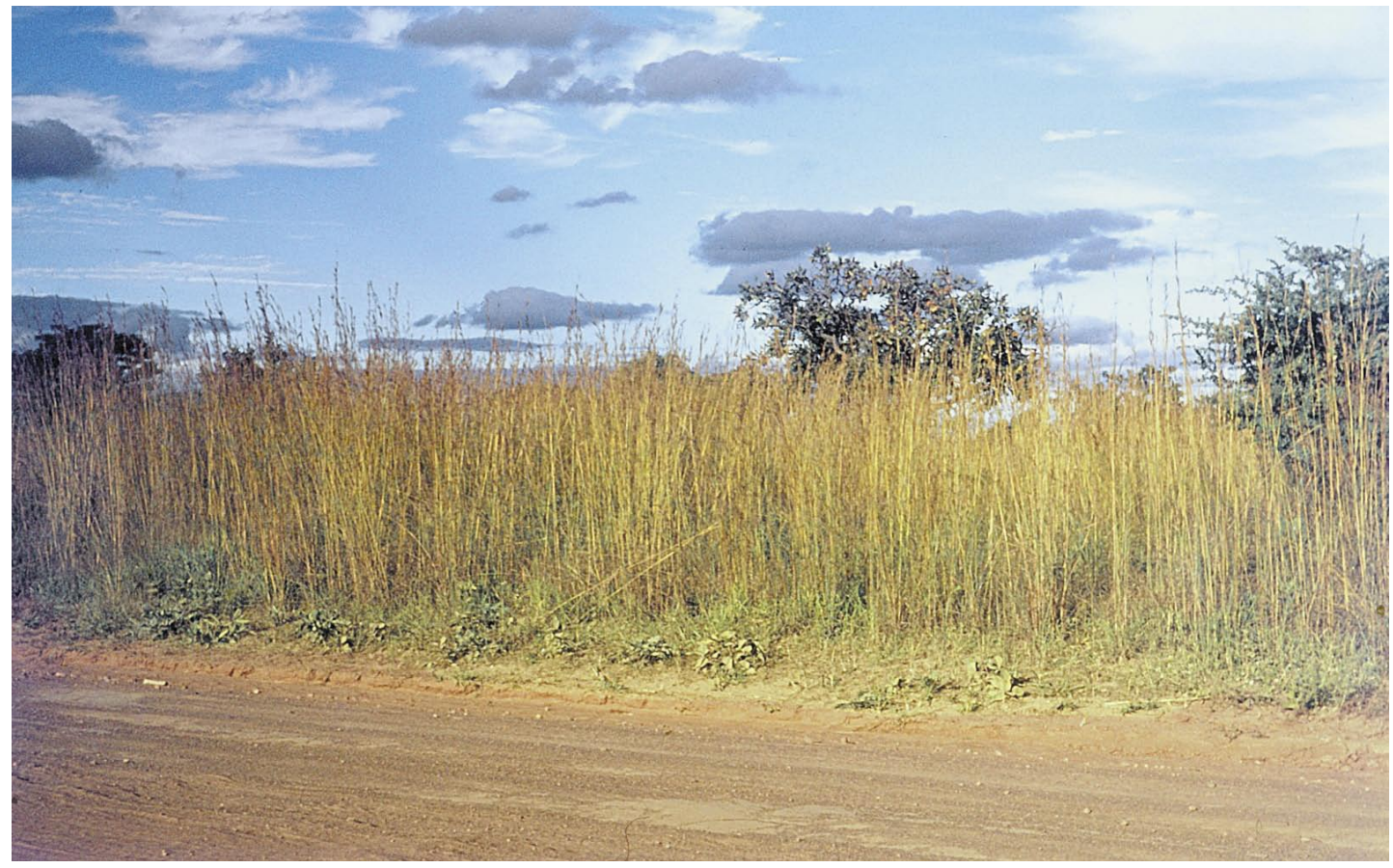

Fig. 9. Lusaka region, observation plot no. 1. Under yellow drying grasses are small pyrophitic plants, April 1973, beginning of dry season. 


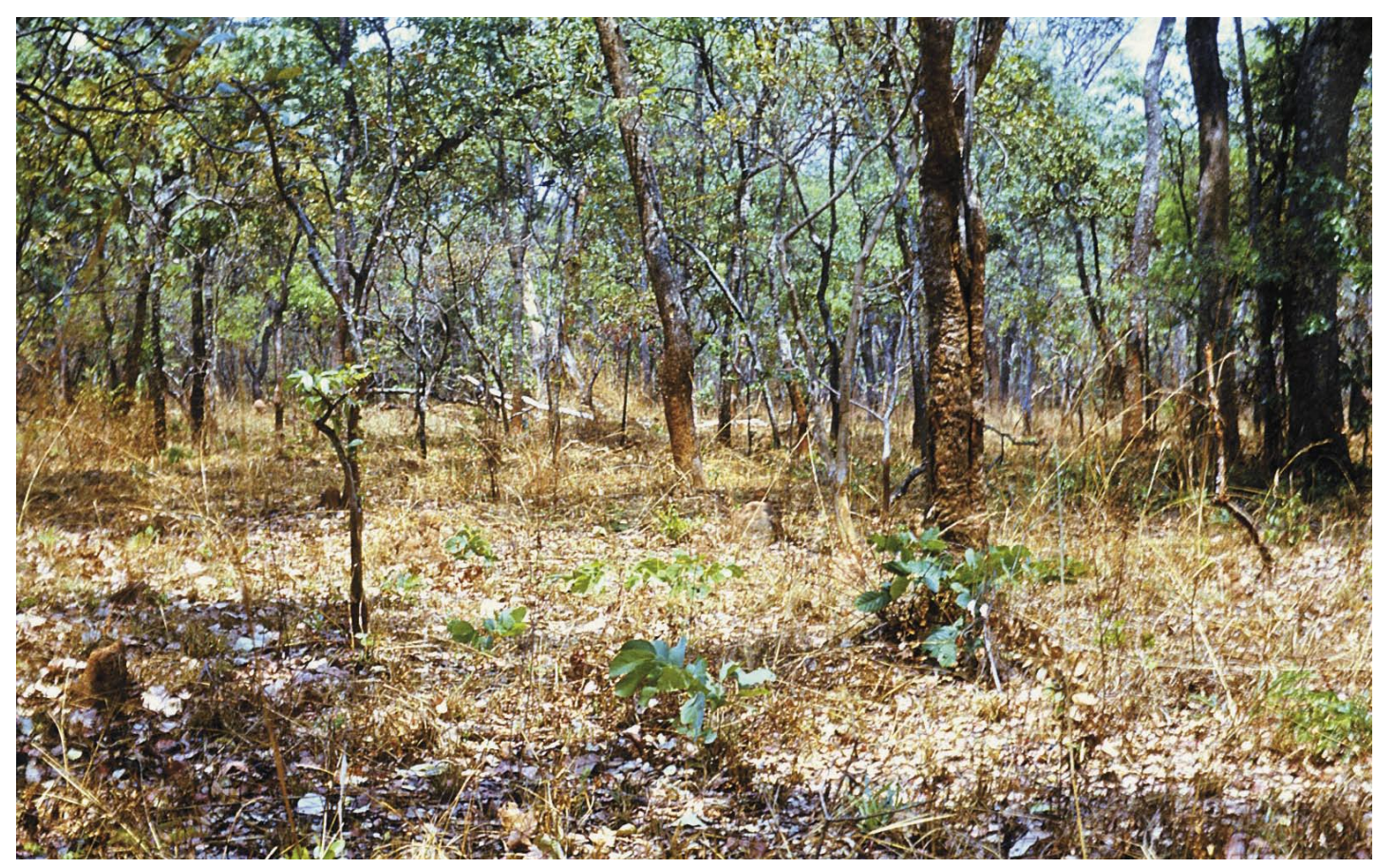

Fig. 10. Miombo woodland, regeneration of various plants (also trees) after a fire. Ndola Nature Reserve, area of burning experiments, 29 September 1972.

blooming of Hibiscus rhodanthus. Its pyrophytic character is therefore confirmed.

The most interesting feature of Hibiscus rhodanthus is its affiliation with the so-called 'geoxylic suffrutices', or 'suffrutices'. Several authors have dealt with the evolution of this group of pyrophytes (e.g., White 1977), which includes, among other plants, Gardenia subacaulis, a species observed together with Hibiscus rhodanthus on the permanent plots near Lusaka; it seems right here to repeat a fragment of a relevant text from a publication by Medwecka-Kornaś (1980).

'Savanna plants grow under the pressure of various stress factors, all of which may have very strong selective effects: burning, overgrazing, seasonal drought, excessive heat and soil poverty'. The suggestion put forward by Exel and Stace (1972) that the key factor is either water stress or the impact of fire seems most plausible. What is important here is that 'a number of normal trees of dry forests and savanna woodlands may persist in accidentally burned areas and produce herba- ceous offsets from the woody underground parts [Fig. 10]. When burning is frequently repeated these offsets closely resemble the growth form of suffrutices. This indicates the way in which the hereditarily fixed life forms of a true geoxylic suffrutex may have developed'.

Almost a century ago, Burtt Davy (1922) presented similar findings. He discussed the features of several plants with a suffrutescent habit, defining them as 'plants producing annual shoots from woody rootstock'. Among them are mentioned some species in common with the vegetation on the permanent plots near Lusaka, such as Parinarium (Parinari) capense, which is presented together with its underground parts in a drawing. In his opinion, the 'suffruticose condition is not merely a temporary expedient, but has become a fixed habit which persists under more favourable conditions'. Some suffrutices which he transplanted 'to more favourable conditions of temperature and soil-moisture, did not show any change of habit after several years of growth'. 
Burtt Davy (1922), like Exel and Stace (1972) and other authors, posits the evolution of suffrutices from 'normal' trees. In the genus Hibiscus some difficulty may result from the fact that it includes only a few tree species, usually small ones, and this may be why there are not many herbaceous plants with woody underground parts in this genus. Among the dozens of Hibiscus species mentioned in Flora Zambesiaca, only five are qualified as geoxylic suffrutices. This makes $H$. rhodanthus a species worthy of attention.

ACKNOWLEDGEMENTS. I am greatly indebted to my husband Jan Kornaś for his assistance in field studies and plant species determination, and to the anonymous reviewer for valuable remarks on the manuscript.

\section{REFERENCES}

BuRTT DAVY J. B. 1922. The suffrutescent habit as an adaptation to environment. J. Ecol. 10: 211-219.

Christensen N. L. 1985. Shrubland fire regimes and their evolutionary consequences. In: S. T. A. PICKETT \& P. S. WHITE (eds), The ecology of natural disturbance and patch dynamics, pp. 85-100. Academic Press INC, Orlando, San Diego, New York etc.

Exell A. W. 1961. Malvaceae. In: A. W. ExELL \& H. WILD (eds), Flora Zambesiaca. 1: 420-511. Kew Publishing and Flora Zambesiaca Managing Committee, London.

EXell A. W. \& STACE C. A. 1972. Patterns of distribution in the Combretaceae. In: D. H. VALENTINE (ed.), Taxonomy, Phytogeography and Evolution, pp. 307-323. Academic Press, London and New York.

FANSHAWE D. B. 1971. The vegetation of Zambia. Forest Research Bulletin, Kitwe 7: i-iv, 1-67 \& maps 1-3.

FANSHAWE D. B. 1973. Check list of the woody plants of Zambia showing their distribution. Forest Research Bulletin, Kitwe 22: 1-48.
GILLON D. 1983. The fire problem in tropical savannas. In: E. BOUlRIERE (ed.), Tropical savannas, pp. 617-461. Elsevier Scientific Publishing Company, Amsterdam.

KoRNAŚ J. 1979. Distribution and ecology of the pteridophytes in Zambia. Państwowe Wydawnictwo Naukowe, Warszawa, Kraków.

Krohmer J., Scheiter S. \& Higgins S. 2012. Konkurrenzkampf in der afrikanischen Savanne. Das SeckenbergWissenschaftsmagazin, Frankfurt am Main 142(9/10): 298-306.

KuLl C. A. 2004. Isle of fire. The political ecology of landscape burning in Madagascar. University of Chicago Press, Chicago.

LÜtTGE U. 2008. Physiological ecology of tropical plants. Second edition. Springer-Verlag, Berlin, Heidelberg.

MedweCKA-KornAŚ A. 1980. Gardenia subacaulis Stapf \& Hutch.: a pyrophytic suffrutex of the African savanna. Acta Bot. Acad. Sci. Hung. 26(1-2): 131-137

MEDWECKA-KoRnAŚ A. \& KoRnAŚ J. 1985. Fire resistant sedges (Cyperaceae) in Zambia. Flora 176: 61-71.

PHILLIPS J. 1974. Effects of fire in forest and savanna ecosystems of Sub-Saharan Africa. In: T. T. KOZŁOWSKI \& C. E. AHLGREN (eds), Fire and ecosystems, pp. 435-481. Academic Press, New York etc.

Pócs T. 1993. The pteridological research of Professor Jan Kornaś in Africa. Fragm. Florist. Geobot., Suppl. 2(1): 67-70.

STRŘMGAARD P. 1992. Immediate long-term effects of fire and ash fertilization on a Zambian miombo woodland soil. Agriculture Ecosystems and Environment 41: 19-27.

VAN LANGeVelde F., van de ViJVer C. A. D. M., Kumar L., VAN DE KOPPEL J., DE RIDDER N., VAN ANDEL J., SKIDMORE A. K., HeArne J. W., StroosniJder L., BOND W. J., PRINS H. H. T. \& RIETKERK M. 2003. Effects of fire and herbivory on the stability of savanna ecosystems. Ecology 84(2): 337-350.

White F. 1962. Forest flora of Northern Rhodesia. Oxford University Press, London.

White F. 1977. The underground forests of Africa: a preliminary review. Gard. Bull. Singapore 29: 37-71. 